レジスタンス運動後の乳清たんぱく質の摂取が高齢女性のサルコペニア治療と QOLに与える効果：無作為化比較試験

\author{
森 博康 ${ }^{*}$, 徳田 泰伸 $^{2}$
}

\title{
Effect of whey protein supplementation after resistance exercise on the treatment of sarcopenia and quality of life among older women with sarcopenia: A randomized controlled trial
}

\author{
Hiroyasu Mori ${ }^{1^{*}}$ and Yasunobu Tokuda ${ }^{2}$ \\ 1徳島大学先端酵素学研究所, 干770-8503 徳島県徳島市蔵本町 3 丁目 18番地の 15 (Institute of Advanced Medical Sciences, \\ Tokushima University, 3-18-15 Kuramoto-cho, Tokushima, Tokushima 770-8503, Japan) \\ 2一般社団法人兵庫ロコモ・シニア・寺子屋， 675-0082 兵庫県明石市大久保町高丘 7-26-8 (Hyogo Locomotion-senior- \\ tera-koya, General Incorporated Association, 7-26-8 Okubo-cho Takaoka, Akashi, Hyogo 675-0082, Japan)
}

Received: February 12, 2021 / Accepted: March 9, 2021

\begin{abstract}
To evaluate the effectiveness of a 24-week nutritional supplementation program involving whey protein intake after resistance exercise in treatment of sarcopenia and quality of life (QOL) among older women with sarcopenia, we carried out a pilot study, randomized controlled trial among elderly individuals with sarcopenia, aged 65-years or older, who were allocated to three groups: exercise and whey protein supplementation (Ex+Whey) group, exercise (Ex) group, and whey protein supplementation (Whey) group. Sarcopenia was defined using the Asian Working Group for sarcopenia 2014 criteria, as follows: low hand-grip strength $(<18.0 \mathrm{~kg})$ or slow gait speed $(<0.8 \mathrm{~m} / \mathrm{sec})$, and low skeletal muscle mass index (SMI, $<5.7 \mathrm{~kg} /$ $\mathrm{m}^{2}$ ). A 24-week program of resistance exercise, carried out twice per week, was combined with whey protein supplementation, involving $11.0 \mathrm{~g}$ of protein and 2,300 $\mathrm{mg}$ of leucine. After the 24-week intervention period, the $\mathrm{Ex}+$ Whey group $(\mathrm{n}=20)$ showed a decrease in sarcopenia, lower SMI, lower grip strength, and increase in physical QOL score (sarcopenia; $\mathrm{p}=0.004$, SMI and grip strength; $\mathrm{p}=0.008$, QOL; $\mathrm{p}=0.027$ ). After the 24-week intervention period, the Whey group $(\mathrm{n}=20)$ showed a decrease in sarcopenia and lower SMI (all $\mathrm{p}=0.017)$. The Ex-group $(n=19)$ did not show a decrease in sarcopenia, lower SMI, and lower grip strength. These results suggest that resistance exercise and whey protein intake in older women with sarcopenia, on the multiple outcome measures such as improves lower SMI, lower grip strength, and physical QOL. However, there were no between-group differences in the change from the pre- to the post-intervention period at 24 weeks in the lower SMI and lower grip strength. In this study, the intervention effect of Ex+Whey could not be clearly shown in the outcome measures.
\end{abstract}

Jpn J Phys Fitness Sports Med, 70(3): 207-218 (2021)

Keywords : sarcopenia, whey protein resistance exercise, physical function, quality of life

\section{緒言}

我が国では超高齢化に伴い後期高齢者が著しく増加し ており，低栄養や不活動を伴うことでサルコペニアを発 症するリスクが高まる11. なかでも，日本人の高齢女性 は, 男性と比べ転倒発生リスクが高いことが報告されて おり ${ }^{2)}$, 日常生活での骨格筋量や筋力, 身体機能の維持・

*Correspondence: hiroyam31@gmail.com
増加を目的とした対策が重要である。

一般高齢者の骨格筋量の維持・増加のためには総エネ ルギーや総たんぱく質の摂取量を適切に充足した栄養療 法とレジスタンス運動を中心とした運動療法が薦められ ている3,4).しかし，サルコペニアを発症した高齢者にお いて栄養療法と運動療法の併用介入が各単独介入と比心゙ 骨格筋量や筋力，身体機能が増加し，さらには生活の質 （Quality of life；QOL）が改善するかについて十分な工 ビデンスが得られていない 
我が国で作成されたサルコペニア診療ガイドライン 2017年度版 ${ }^{5}$ では Asian Working Group for Sarcopenia （AWGS）基準でサルコペニアをスクリーニングし，サ ルコペニアに該当しない健常高齢者は発症予防を目指し た予防介入に関するエビデンスの創出を目指すこと, サ ルコペニアに該当する高齢者は寛解を目指した治療介入 に関するエビデンスの創出を目指すことが示されてい る.さらに本ガイドラインではサルコペニア治療におい て, 運動療法や栄養療法の介入が推奨されるが, 複数の 治療方法を併用介入した無作為化比較試験 (Randomized Controlled Trial；RCT）によるサルコペニアの寛解とそ の診断構成要素（骨格筋量の低下, 筋力の低下, 身体機能 の低下）の寛解を目指したアウトカム改善効果について 明らかではないと示している.

レジスタンス運動後，24-48時間に渡り筋たんぱく合 成が高まる ${ }^{6,7)}$. 筋たんぱく合成の増大は運動終了後, 時 間経過と共に低下するため, 運動終了後の早急なたんぱ く質摂取が必要になる ${ }^{6-8)}$. なかでも牛乳及び乳製品由 来の乳清たんぱく質は分岐鎖アミノ酸が多く含まれ, カ ゼインたんぱく質と比べ消化吸収が早く高齢者の筋たん ぱく合成量を高めることが報告されている ${ }^{3,4,8,9)}$. 筆者ら はこれまでにフェーズIのRCTとして, AWGS2014年 基準でサルコペニアに該当していない健常高齢女性を対 象に24週間に渡りレジスタンス運動後に摂取する乳清た んぱく質との併用介入が運動または乳清たんぱく質摂取 の各単独介入と比べて, 四肢の骨格筋量や膝伸展筋力が 有意に増加したことを報告している ${ }^{10)}$. 筆者らのフェー ズ I の $\mathrm{RCT}^{10)}$ はサルコペニアに該当していない健常高 齢者を対象としたため, サルコペニア予防介入として, 運動と栄養療法の併用効果の有効性を明らかにした。

これまでにサルコペニアの高齢者を対象に骨格筋量や 筋力の数值をアウトカムとした RCT 研究は散見される が, サルコペニアの寛解者数をアウトカムとしたRCTの 報告はない．またサルコペニアに該当する高齡女性の身 体的QOL改善をアウトカムとしたRCT の報告はない.

本研究の目的はサルコペニアに該当する高齝女性を対 象とし, レジスタンス運動と乳清たんぱく質の摂取の併 用介入が各単独介入群と比ベ, サルコペニアとその診断 構成要素 (骨格筋量, 筋力, 身体機能の低下) の寛解, さ らには身体的QOL改善に与える効果の可能性について, フェーズIの RCTで検証する。さらに本研究では, 運動 と乳清たんぱく質の併用介入によってサルコペニアを寛 解した高齢女性の臨床的特徵を明らかにする.

\section{方法}

対象者 兵庫県 6 市在住の高齢者コミュニティ 5 施設 ( $\mathrm{n}=304)$ と通所介護（介護予防型も含む）が利用可能な 5 施設（要支援 1,2 と要介護 1 に該当する, $\mathrm{n}=63$ ）に
通う65歳以上の女性 367 名を対象に募集を行った。本研 究では糖尿病や慢性腎臟病等の治療や重度の認知症, 捸 食苝下障害・関節障害に該当する症例 $(n=33)$ は運動 及び食事制限を伴うため, サルコペニア症例のスクリー ニングから除外した，その後, 握力と歩行速度, 四肢骨 格筋量指数 (Skeletal muscle mass index; SMI) の計 測を行い, サルコペニア症例のスクリーニングを行っ た. 本研究ではAsian Working Group for Sarcopenia (AWGS) 2014年基準 ${ }^{1)}$ で握力低下あり（18 kg 未満）ま たは歩行速度低下あり $(0.8 \mathrm{~m} /$ 秒未満 $)$, かつSMI低下 あり $\left(5.7 \mathrm{~kg} / \mathrm{m}^{2}\right.$ 未満）に該当しない症例 $(\mathrm{n}=249)$ を 除外し, サルコペニア症例 85 名を対象に研究参加に関 する説明を行った。このうち研究参加を辞退した 16 名 を除外し, 同意を得た 69 名を本研究の参加対象とした。 研究開始時点で, サルコペニアの寛解者数をアウトカム 指標にした先行 RCTが見当たらなかったため, 本研究 はサンプルサイズの計算を行なわず, 探索的試験として 実施することにした。また, 本研究は対象者と研究者及 び研究協力者がブラインド化されていない非盲検化試験 として実施した。な扮本研究は人を対象とする医学系研 究に関する倫理指針に基づき, 徳島大学病院医学系研究 倫理審査委員会（3113）の承認を得て実施した（臨床試 験登録番号：UMIN000030992)。本研究では年齢と募集 施設（コミュニティまたは通所利用あり）をもとに層別 化し以下の 3 群に無作為に割り付け，24週間の介入を 行った.

・レジスタンス運動群：運動群 23 名（コミュニティ 14 名, 通所 9 名), 週 2 回のレジスタンス運動を実践する.

・乳清たんぱく質摂取群 : 乳清群 23 名（コミュニティ 14 名, 通所 9 名), 乳清たんぱく質を週 2 回摂取する. ・レジスタンス運動+乳清たんぱく質摂取群：運動+乳 清群 23 名 (コミュニティ 14 名, 通所 9 名), 週 2 回の レジスタンス運動終了直後に乳清たんぱく質を摂取す る。な㧍, 本研究では介入開始前, 習慣的にレジス夕 ンス運動を実践し、たんぱく質サプリメントを摂取し ている症例は含まれていなかった。

本研究の主要アウトカムは介入後のサルコペニア該当 者の減少 (寛解) および, 身体的 QOLの改善とした。 な拉, 本研究ではサルコペニア診断の構成要素であるSMI低下 あり $\left(5.7 \mathrm{~kg} / \mathrm{m}^{2}\right.$ 未満), 握力低下あり (18 kg未満), 歩 行速度低下あり (0.8 m/秒未満) の減少を主要アウトカ ム指標として評価した。

\section{評価項目}

\section{1) 身体計測}

多周波数のインピーダンス法が内蔵された体組成計 (In Body bioelectrical impedance analyzer 430, In Body ジャパン, 東京, 日本）を用いて体重, BMI, 四肢の骨格 
筋量を求めた ${ }^{1,5)}$. SMIは四肢の骨格筋量を身長 $(\mathrm{m})$ の 2 乗で除して算出した。なお，身長は立位で身長計を使 用し, 直立姿勢で計測が困難な対象者は石原式身長測定 法でメジャーを使用して計測した ${ }^{11)}$.

\section{2) 筋力}

握力はデジタル握力計 (T.K.K5401, 竹井機器工業, 新 潟, 日本) を用いて左右 2 回測定し, 最大值を記録した ${ }^{1,5)}$. 膝伸展筋力は徒手筋力計 (ミュータス, アニマ, 東京, 日 本）を用いて左右 2 回測定し, 最大值を記録した.

\section{3）身体機能}

通常歩行速度は $11 \mathrm{~m}$ の歩行路のうち $3-8 \mathrm{~m}$ 区間（距 離 $5 \mathrm{~m}$ ）を普段通りの速さで歩いたときの時間を 0.01 秒 単位で 2 回実施し, 最大の速度 ( $\mathrm{m} /$ 秒) を記録した ${ }^{1,5)}$. SMI と握力, 膝伸展筋力, 歩行速度は介入開始前と介入 終了後の合計 2 回収集した.

\section{$4 ）$ 健康関連 QOL}

健康関連QOLは，自記式質問紙（Short form Health servey, iHope, 京都, 日本) を用いて身体的QOLをスコ アリング（－100点）した ${ }^{12}$. QOLは介入開始前と介 入終了後の合計 2 回収集した.

\section{5 ）総エネルギー摂取量, 総たんぱく質摂取量}

栄養摂取状況調査は介入開始前と介入終了前の連続し た各 3 日間の食事について聞き取り調査を行った。また, 記入漏れ等がないよう対象者本人拉よび同居者等への食 物摂取状況の聞き取り調查を個別に実施した。栄養素等 摂取量の計算は, 五訂増補日本食品標準成分表と日本人 の食事摂取基準 (2015年版 ${ }^{13)}$ に準拠した栄養計算ソフ ト（エクセル栄養君, 建帛社, 東京, 日本) を使用した。 調査項目は目標掞よび現体重（kg) あたりのたんぱく質 摂取量（g/日）と目標体重あたりの総エネルギー摂取 量（g/日）とした。目標体重は身長（m）を2乗し， 22 を乗じて算出した。 なお，本研究では介入開始時の全症 例（ $\mathrm{n}=69 ）$ の BMIの四分位数範囲は18.7-21.1であり， 低栄養傾向（BMI $\leqq 20 \mathrm{~kg} / \mathrm{m}^{2}$ ) であったため, 目標体 重をBMI22.0に設定した。栄養状態の評価はMini Nutritional Assessment-Short Form $\left(\mathrm{MNA}^{\circledR}-\mathrm{SF}\right.$, Nesle Nutrition Institute) ${ }^{14)}$ を用いた。

\section{6 ）身体活動量}

加速度センサが内蔵された活動量計（EZ-063 CALORIZM, TANITA, 東京, 日本) を装着するよう求め, 総 歩行数（歩/日）を算出した. 介入前の 1 週間に渡り記録 した.

\section{介入方法}

\section{1) 運動方法}

レジスタンス運動は, 運動群と運動+乳清群に実践す るよう求めた、筆者らの先行研究 ${ }^{10)}$ を参考とし, 自体 重または伸縮性のあるエラスティックバンド（THERABAND, The Hygenic Corporation, アメリカ) を利用し たレジスタンス運動の 7 種目（自体重 2 種目：スクワッ ト [大腿部］とレッグエクステンション [大腿部].エラ スティックバンド 5 種目 ; スクワット [大腿部 $],$ レッグ エクステンション [大腿部], ローウイング [背部, 上腕 部], アームカール [上腕部], プッシュアップ [胸部, 上 腕部, 肩部]）とした，運動強度は主観的運動強度で楽〜 ややきついと感じる負荷とし, 週 2 回実践した（1-6 週目：自体重10回×2セット, エラスティックバンド10 回 $\times 2$ セット, 7-12週目：自体重10回 $\times 3$ セット, エラ スティックバンド 10 回 $\times 2$ セット，13-18週目：自体重 15 回 $\times 2$ セット, エラスティックバンド15回× 2 セット, 19-24週目：自体重 15 回 $\times 3$ セット, エラスティックバ ンド 15 回 $\times 3$ セット)。運動実践時間は準備体操を含め て60-90分間であった。なお，レジスタンス運動は昼食 2 時間後から夕食の 2 時間前までに済ませるよう求め た。本研究は対象者の生活環境をもとにコミュニティ及 び施設での参集型指導または，在宅での訪問型指導に分 けて介入を行った。研究者らが作成した運動実践プログ ラムとリーフレットをもとに研究協力者である運動指導 者や介護福祉士らが介入を行った，介入期間中，全対象 者には介入前と同様の日常活動（散歩やラジオ体操, レ クレーション）で過ごすよう依頼した，運動群と運動+ 乳清群には独自の判断でレジスタンス運動以外の運動を 新たに実践しないことを求めた

\section{2）乳清たんぱく質の摂取方法}

乳清たんぱく質が含まれた試験食（HINEXリハデイ ズ, 大塚製薬工場, 徳島, 日本) は, 乳清群と運動 +乳清 群に提供した。本試験食 1 回で摂取できるたんぱく質 11 $\mathrm{g}$, 脂質 $2.22 \mathrm{~g}$, 炭水化物 $24.0 \mathrm{~g}$, ロイシン $2,300 \mathrm{mg}$, エ ネルギー $165 \mathrm{kcal}$ である。本研究では食事摂取量が不足 している対象者が含まれることを想定し，高用量のたん ぱく質量が含まれた試験食の摂取後の食事量が十分に喫 食できなくなる可能性があると考えた，そこで，本研究 では筆者らの先行研究 ${ }^{10)}$ で使用した粉末状の乳清たんぱ く質（たんぱく質量 $22.3 \mathrm{~g} / 1$ 回分）ではなく，低用量の たんぱく質が含まれた清涼飲料の試験食で提供すること にした，本試験食を採用した根拠として，筋たんぱく合 成を高める 1 回あたりのロイシン量を $1200 \mathrm{mg}$ 以上の高 用量とすること ${ }^{11)}$ ，レジスタンス運動に伴い消費したエ ネルギー量を試験食で補充し，エネルギー摂取不足を防 ぐためである。運動＋乳清群は試験食を週 2 回の運動終 
了後 10 分以内に摂取するよう求めた，乳清群は試験食を 週 2 回, 昼食 3 時間後から夕食の 2 時間前までに摂取す るよう求めた。

\section{3）介入期間中の食事管理方法}

介入期間中，全被験者は総エネルギー量を $30 \mathrm{kcal} / \mathrm{kg}$ 目標体重/日以上, 総たんぱく質量を $1.2 \mathrm{~g} / \mathrm{kg}$ 目標体重/ 日以上を摂取できるよう食事管理を行った 3.4$)$ 。筆者ら のフェーズ I の $\mathrm{RCT}^{10)}$ では, 介入前の BMI は $22.4 \pm 2.0$ であったため, 介入中は現体重あたりのたんぱく質 1.2 $\mathrm{g} / \mathrm{kg}$ 現体重/日以上摂取できるよう食事管理を行った。 本研究のフェーズ II の全対象者はBMIが低く，MNA$\mathrm{SF}$ は低栄養の疑いの可能性（四分位数範囲：MNASF9-11点）がある症例が多いため, 目標体重あたりの 総エネルギーと総たんぱく質量を設定し食事管理を行う ことにした. Table 1に食事管理方法を示した，本研究 では被験者の目標体重をもとに給与栄養目標量を設定 し， 3 大栄養素の各エネルギー比率は日本人の食事摂取 基準2015年 ${ }^{13)}$ を参考にたんぱく質13〜20\%，脂質 20〜
$30 \%$ ，炭水化物 50 65\%とした。ささらに各給与栄養目標 量をもとに各食品構成表を作成し（Table 1), 食品べー スでの食事管理を行うと共に，個別栄養指導，モデル献 立の作成, 栄養管理された宅配形式での食事提供, 同居 者や食事提供者等を含めた食事指導を行った。

統計解析 本研究で得られたデー夕の統計処理はIBM SPSS Statistics 22（日本アイ・ビー・エム株式会社）を 使用した，全ての評価項目において，Shapiro-Wilkの正 規性の検定を行い，正規分布または非正規分布を確認し た後，各統計手法を決定した，正規分布を認めた変数は 平均值士標準偏差で示し, 非正規分布を認めた変数は中 央值（四分位区間 25 パーセンタイル，75パーセンタイル） で示した，介入前の被験者の身体的特徵，募集施設，サ ルコペニアあり, SMI低下あり, 握力低下あり, 歩行速 度低下あり, 身体計測, 筋力, 身体機能, QOL, 総工 ネルギー摂取量, 総たんぱく質摂取量, 総歩行数の群間 差の比較は対応のない $t$-検定またはMann-Whitneyの $\mathrm{U}$ 検定， $\chi^{2}$ 検定を用いた。介入中の運動または乳清たん

Table 1. The detailed nutritional management regimen

I . Recommendation of total energy and macronutrients intake amount in this study

\begin{tabular}{|c|c|c|c|}
\hline $\begin{array}{c}\text { Total energy } \\
(\mathrm{kcal} / \mathrm{day})\end{array}$ & $\begin{array}{c}\text { Total } \\
\text { protein } \\
(\mathrm{kcal} / \mathrm{day})\end{array}$ & Total fat & $\begin{array}{c}\text { Total } \\
\text { carbohydrate } \\
(\mathrm{kcal} / \mathrm{day})\end{array}$ \\
\hline 1450 & 55 & 37 & 225 \\
\hline 1550 & 60 & 39 & 240 \\
\hline 1650 & 65 & 43 & 250 \\
\hline 1700 & 70 & 44 & 255 \\
\hline 1750 & 75 & 46 & 260 \\
\hline
\end{tabular}

II. Food group (g/day)

\begin{tabular}{|l|c|c|c|c|c|}
\hline & $\begin{array}{c}1450 \\
(\mathrm{kcal} / \text { day })\end{array}$ & $\begin{array}{c}1550 \\
(\mathrm{kcal} / \text { day })\end{array}$ & $\begin{array}{c}1650 \\
(\mathrm{kcal} / \text { day })\end{array}$ & $\begin{array}{c}1700 \\
(\mathrm{kcal} / \text { day })\end{array}$ & $\begin{array}{c}1750 \\
(\mathrm{kcal} / \text { day })\end{array}$ \\
\hline Cereals (g/day) & 270 & 285 & 300 & 300 & 300 \\
\hline Potatoes (g/day) & 30 & 30 & 30 & 50 & 60 \\
\hline Fish and shellfish (g/day) & 40 & 40 & 50 & 60 & 70 \\
\hline Meats (g/day) & 40 & 45 & 55 & 60 & 70 \\
\hline Eggs (g/day) & 40 & 40 & 40 & 40 & 40 \\
\hline Milk and dairy product (g/day) & 150 & 180 & 180 & 180 & 180 \\
\hline $\begin{array}{l}\text { Bean and soybean product } \\
\text { (g/day) }\end{array}$ & 50 & 60 & 70 & 70 & 80 \\
\hline Vegetables (g/day) & 300 & 300 & 300 & 300 & 320 \\
\hline Fruits (g/day) & 50 & 60 & 60 & 70 & 80 \\
\hline Fat and oil (g/day) & 10 & 10 & 13 & 13 & 13 \\
\hline $\begin{array}{l}\text { Sugar and confectioneries } \\
\text { (g/day) }\end{array}$ & 10 & 10 & 15 & 15 & 15 \\
\hline
\end{tabular}


ぱく質摂取の実践率はMann-WhitneyのU検定を用い た。運動十乳清群及び運動群, 乳清群の群内における介 入後のサルコペニアあり, SMI低下あり，握力低下あり， 歩行速度低下あり, 身体計測, 筋力, 身体機能, QOL, 総エネルギー摂取量, 総たんぱく質摂取量の変化を検討 するため, 対応のある $t$ 一検定またはWilcoxonの符号付 き順位和検定， $\chi^{2}$ 検定を用いた。 また，介入前後の身体 計測, 筋力, 身体機能, QOL, 総エネルギー摂取量, 総 たんぱく質摂取量の群 (運動群, 乳清群, 運動+乳清群) $\times$ 時間（介入前, 介入後）の交互作用と主効果の検定は, 繰り返しのある二元配置の分散分析を用いた，身体計測， 筋力, 身体機能, QOLの変化率（\% $\%$ : [介入後一介入 前 $] /$ 介入前 $\times 100 ） の$ 群間差の比較は, 非正規分布のた めMann-WhitneyのU検定を用いた，介入後のサルコペ ニアあり, SMI低下あり, 握力低下あり, 歩行速度低下 ありの群間比較は $\chi^{2}$ 検定を用いた。 介入後の運動+乳清 群のサルコペニア寛解ありと寬解なしの群間差の検定 は非正規分布のためMann-WhitneyのU検定を用いた。 なお，有意水準は $5 \%$ （両側検定）とした.

\section{結 果}

介入期間中に研究から脱落した症例（運動群：4名, 乳清群: 3 名, 運動+乳清群: 3 名)を除外し, 運動群 19 名, 乳清群 20 名, 運動+乳清群 20 名を対象に本研究結果の 分析を行った (Fig. 1). 脱落理由はFig. 1に示した. 脱 落理由は研究参加の意欲低下 $(n=3)$, 連絡がつかない ため追跡不能 $(n=2)$, 試験食の嗜好が合わないため研 究参加を中止した $(n=2)$, 転居 $(n=1)$, 首関節の痛み $(n=1)$, 入院 $(n=1)$ であった。このうち宅配形式の食 事提供の履歷がある症例は運動群 6 名, 乳清群 5 名, 運 動+乳清群 7 名であった.

介入前の身体特徵を Table 2 に示した，介入前の身体 特徵に 3 群間で有意な違いはなかった。 介入期間中, 対 象者の飲み忘れや私的な都合等もあり, 合計 48 回の運動 実践または乳清たんぱく質摂取の実践率は運動群 $73.4 \pm$ $4.1 \%$, 乳清群は $75.6 \pm 6.5 \%$, 運動+乳清群は $74.6 \pm 6.4 \%$ であり， 3 群間に有意な差を認めなかった，介入前の各 群のSMIや握力, 膝伸展筋力, 歩行速度, 身体的 $\mathrm{QOL}$ に 有意な差を認めなかった。また，介入前の総エネルギー や総たんぱく質摂取量, 総歩行数に有意な差を認めな かった.

サルコペニア及び各診断要素の寛解者数を介入前後で郡 内比較, 介入後の群間比較 サルコペニア及び各診断要 素の寛解者数の介入前後の群内比較及び介入後の群間比 較をTable 3に示した.

介入前と比べ介入後, 運動+乳清群はサルコペニアあ り（ $\mathrm{p}=0.004 ） と \mathrm{SMI}$ 低下あり（ $\mathrm{p}=0.008 ）$, 握力低下あ り（p=0.008）が有意に減少し, 乳清群はサルコペニア あり（ $\mathrm{p}=0.017 ）$ と SMI低下あり（ $\mathrm{p}=0.017 ）$ が有意に減 少した.

介入後の運動+乳清群のサルコペニアあり（介入後の サルコペニアあり13名, なし 7 名）と運動群のサルコペ ニアあり（介入後のサルコペニアあり17名, なし 2 名） を $\chi^{2}$ 検定で群間比較したところ，両群間で有意な差を認 める傾向があった（運動＋乳清群と運動群； $\mathrm{p}=0.070$ ). また, 介入後の運動+乳清群の握力低下あり（介入後の 握力低下あり 14 名, なし 6 名）と乳清群の握力低下あり （介入後の握力低下あり19名, なし 1 名）を $\chi^{2}$ 検定で群間 比較したところ，両群間で有意な差を認めた（運動+乳 清群と乳清群 ; $\mathrm{p}=0.037$ ).

介入前後の身体計測, 筋力, 身体機能, QOL, 総エネルギー 摂取量, 総たんぱく質摂取量を群内比較 介入前後の身 体計測, 筋力, 身体機能, QOL, 総エネルギー摂取量, 総たんぱく質摂取量の比較を Table 4 に示した.

介入前後の身体計測, 筋力, 身体機能, QOL, 総工六 ルギー摂取量, 総たんぱく質摂取量の群 (運動群, 乳清群, 運動＋乳清群） $\times$ 時間（介入前, 介入後）の交互作用と主 効果を繰り返しのある二元配置の分散分析を用いて検定 したところ, 握力と膝伸展筋力に有意な交互作用を認め (握力; $\mathrm{p}=0.007$, 膝伸展筋力 ; $\mathrm{p}=0.001$ ), 体重と SMI, 握力, 膝伸展筋力, 総エネルギー摂取量, 総たんぱく質 摂取量に有意な主効果を認めた（体重と SMI； $\mathrm{p}=0.001$, 握力と膝伸展筋力 ; $\mathrm{p}=0.002$, 総エネルギー摂取量と総た んぱく質摂取量 $; p<0.001)$.

介入前と比べ介入後, 運動群, 乳清群, 運動+乳清群 共にSMIは有意に増加し（運動群 : $\mathrm{p}=0.024$, 乳清群と 運動+乳清群 : $\mathrm{p}=0.003)$, 運動群と運動+乳清群は握力 (運動群 : $\mathrm{p}=0.015$, 運動+乳清群 $: \mathrm{p}=0.010$ ) と膝伸展筋 力 (運動群 : $p=0.012$, 運動+乳清群 $: p=0.001)$ が有意 に増加した，介入前と比べ介入後, 運動+乳清群は身体 的 QOLが有意に増加していた（ $\mathrm{p}=0.027 ）$ が, 運動群と 乳清群の身体的 QOLは有意な増加を認めなかった。一 方で, 介入前と比べ介入後, 乳清群は歩行速度が有意に 低下していた（p=0.048）。

介入前と比べ介入後, 運動群, 乳清群, 運動+乳清群 共に総エネルギー摂取量（各群共に $\mathrm{p}<0.001 ）$ と総たん ぱく質摂取量（各群共に $\mathrm{p}<0.001 ） か ゙$ 有意に増加した。

介入後の身体計測, 筋力, 身体機能, QOLの変化率を群 間比較 介入前後の身体計測, 筋力, 身体機能, QOL の 変化率の群間比較を Table 5 に示した。運動+乳清群は 乳清群と比べて $\% \Delta$ 握力，\% $\%$ 膝伸展筋力， $\% \Delta$ 歩行速 速度が有意に高值であった $(\% \Delta$ 握力 $: \mathrm{p}=0.007, \% \Delta$ 膝 伸展筋力 : $\mathrm{p}=0.002, \% \Delta$ 歩行速度 $: \mathrm{p}=0.045)$. 運動 + 乳 


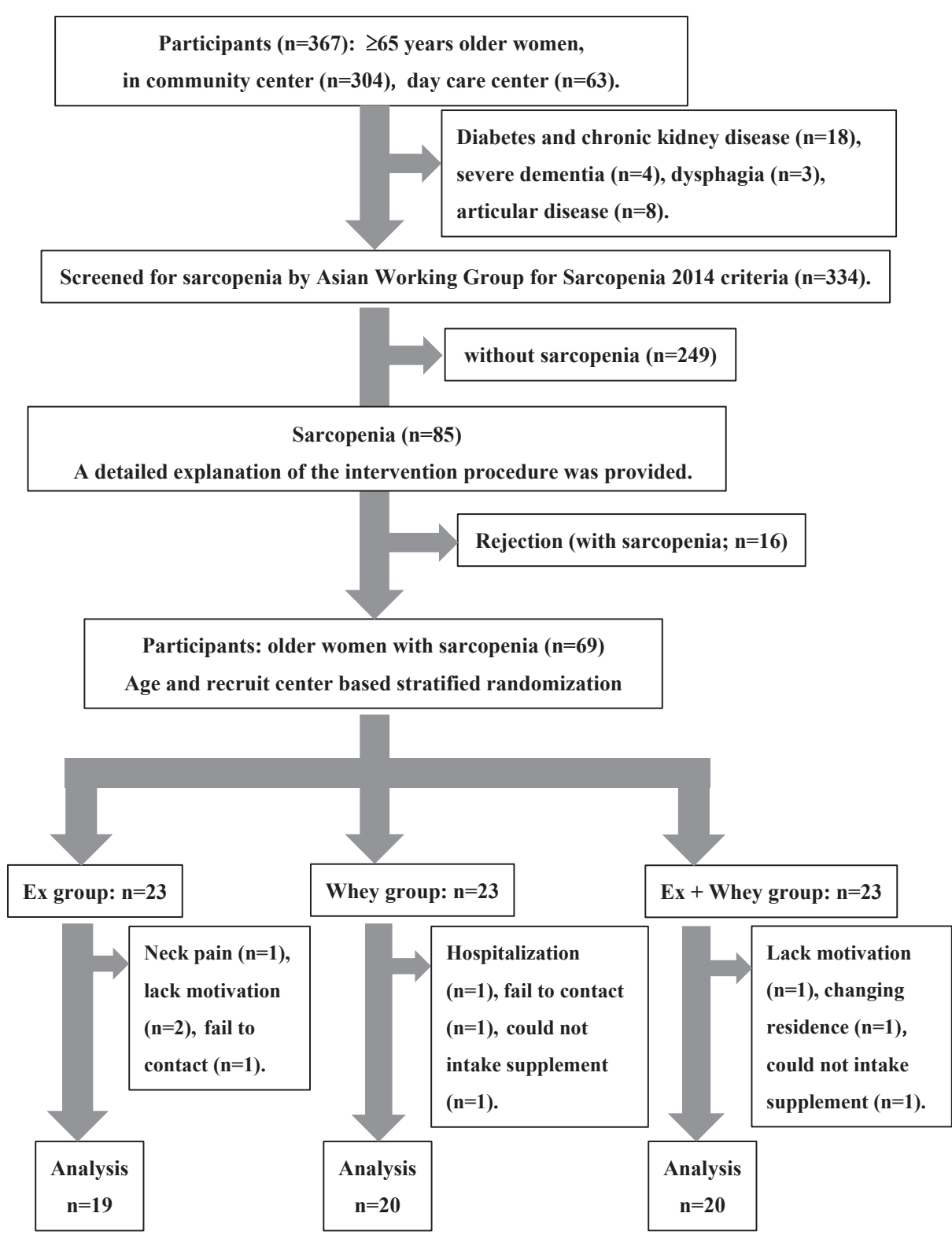

Fig. 1 Flow chart of study participants

Participants was older women with sarcopenia were randomly allocated to one of the three experimental groups: completing the exercise intervention with whey protein supplementation following (Ex + Whey), completing only the exercise intervention (Ex group) and ingestion of the whey protein supplementation only (Whey group).

清群は運動群と比べて, \% $\Delta \mathrm{SMI}, \% \Delta$ 握力, $\% \Delta$ 膝伸 展筋力, $\% \Delta$ 歩行速度に有意な差を認めなかった。また, 乳清群は運動群と比べて $\% \Delta$ 握力, $\% \Delta$ 膝伸展筋力が有 意に低值であった（\% $\%$ 握力 $: \mathrm{p}=0.006, \% \Delta$ 膝伸展筋力 :

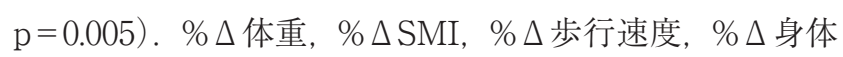
的QOLはいずれも群間差を認めなかった。

\section{運動+乳清群の介入後のサルコペニア寛解ありと寛解な} しの比較 介入後, サルコペニアを寛解した 7 名と寛解 しなかった13名の臨床的特徵を群間比較したところ, サ ルコペニアを寛解した 7 名は，運動実践と乳清たんぱく 質摂取の遵守率（\%）が有意に高值であり（中央值 [25
パーセンタイル, 75パーセンタイル $]$ : 寛解あり $80.0[70.3$, 83.3］\%, 寛解なし 72.9 [60.4, 83.3］％, 寛解あり 7 名とな し 13 名の比較 $\mathrm{p}=0.046)$ 介入終了時の総たんぱく質摂取 量が有意に高值であった（中央值 [25パーセンタイル， 75パーセンタイル $]$ : 寛解あり $1.25[1.23,1.28] \mathrm{g} / \mathrm{kg}$ 目標 体重/日, 寛解なし $1.20[1.05,1.28] \mathrm{g} / \mathrm{kg}$ 目標体重/日, 寛 解あり 7 名となし 13 名の比較 $\mathrm{p}=0.037)$.

\section{考察}

これまでに筆者らはフェーズIの RCTとして， AWGS2014基準でサルコペニアに該当しない健常高齢 女性を対象に 24 週間に渡るレジスタンス運動と乳清たん 
Table 2. Physical characteristics of participants, pre-intervention

\begin{tabular}{|l|c|cc|ccc|}
\hline & Ex group (n=19) & $\begin{array}{c}\text { Whey group } \\
(\mathrm{n}=20)\end{array}$ & $\begin{array}{c}P \text {-value } \\
\text { ExvsWhey }\end{array}$ & $\begin{array}{c}\text { Ex+Whey group } \\
(\mathrm{n}=20)\end{array}$ & $\begin{array}{c}P \text {-value } \\
\text { Ex+Whey } \\
\text { vsEx }\end{array}$ & $\begin{array}{c}P \text {-value } \\
\text { Ex+Whey } \\
\text { vsWhey }\end{array}$ \\
\hline Age (years) & $78.1 \pm 4.6$ & $77.0 \pm 4.5$ & 0.432 & $78.1 \pm 2.7$ & 0.748 & 0.331 \\
Body height (cm) & $149.0(143.5,152.0)$ & $149.0(143.8,150.8)$ & 0.672 & $151.5(144.0,153.3)$ & 0.555 & 0.432 \\
BMI (kg/m $\left.{ }^{2}\right)$ & $19.6 \pm 2.2$ & $19.6 \pm 3.0$ & 0.944 & $20.3 \pm 2.5$ & 0.381 & 0.409 \\
Total step (count/day) & $4045(3029,5486)$ & $3962(2790,4649)$ & 0.674 & $3828(3448,5053)$ & 0.811 & 0.871 \\
MNA-SF (score) & $10.0(9.0,11.5)$ & $11.0(9.0,11.3)$ & 0.607 & $10.5(10.0,11.0)$ & 0.288 & 0.782 \\
\hline $\begin{array}{l}\text { Recruit from community/day } \\
\text { services center (n) }\end{array}$ & $12 / 7$ & $12 / 8$ & 0.839 & $12 / 8$ & 0.839 & $\begin{array}{c}\text { Non } \\
\text { analysis }\end{array}$ \\
\hline
\end{tabular}

Average \pm standard deviation, or median (interquartile range). The results of a non-paired t-test, $\chi^{2}$ test, or Mann-Whitney U test showed no differences in the characteristics of the two groups pre-intervention.

24-week intervention period, for the three experimental groups (completing the exercise intervention with whey protein supplementation following [Ex + whey], completing only the exercise intervention [Ex group] and ingestion of the whey protein supplementation only [Whey group]).

BMI, Body Mass Index; MNA-SF, Mini Nutritional Assessment-Short Form.

Table 3. Comparison of sarcopenia, low SMI, low grip strength, and slow gait speed, pre- and post-intervention, within- and between-group.

\begin{tabular}{|c|c|c|c|c|c|c|c|c|c|c|c|c|}
\hline & \multicolumn{3}{|c|}{ Ex group $(n=19)$} & \multicolumn{3}{|c|}{ Whey group $(\mathrm{n}=20)$} & \multicolumn{3}{|c|}{ Ex+Whey group $(n=20)$} & \multirow{2}{*}{$\begin{array}{c}\text { Ex vs } \\
\text { Whey } \\
\text { P-value } \\
\text { vs between }\end{array}$} & \multirow{2}{*}{$\begin{array}{c}\text { Ex vs } \\
\text { Ex+Whey } \\
\text { P-value } \\
\text { vs between }\end{array}$} & \multirow{2}{*}{$\begin{array}{c}\text { Whey vs } \\
\text { Ex+Whey } \\
\text { P-value } \\
\text { vs between }\end{array}$} \\
\hline & & $\begin{array}{l}\text { Post- } \\
\text { tion }\end{array}$ & $\begin{array}{l}P \text {-value } \\
\text { vs within }\end{array}$ & $\begin{array}{r}\text { Pre- } \\
\text { inte }\end{array}$ & $\begin{array}{l}\text { Post- } \\
\text { tion }\end{array}$ & $\begin{array}{l}P \text {-value } \\
\text { vs within }\end{array}$ & $\begin{array}{l}\text { Pre- } \\
\text { inte }\end{array}$ & $\begin{array}{l}\text { Post- } \\
\text { tion }\end{array}$ & $\begin{array}{l}P \text {-value } \\
\text { vs within }\end{array}$ & & & \\
\hline Sarcopenia (n) & 19 & 17 & 0.146 & 20 & 15 & 0.017 & 20 & 13 & 0.004 & 0.239 & 0.070 & 0.490 \\
\hline Low SMI (n) & 19 & 17 & 0.146 & 20 & 15 & 0.017 & 20 & 14 & 0.008 & 0.239 & 0.132 & 0.723 \\
\hline $\begin{array}{l}\text { Low grip strength } \\
\text { (n) }\end{array}$ & 19 & 16 & 0.071 & 19 & 19 & 1.000 & 20 & 14 & 0.008 & 0.267 & 0.292 & 0.037 \\
\hline Slow gait speed (n) & 1 & 2 & 0.515 & 2 & 5 & 0.212 & 3 & 3 & 1.000 & 0.239 & 0.676 & 0.429 \\
\hline
\end{tabular}

Number of sarcopenia, low SMI, low grip strength, slow gait speed. Within and between-group differences were evaluated using a $\chi^{2}$ test; the $\mathrm{P}-$ value is shown.

24-week intervention period, for the three experimental groups (completing the exercise intervention with whey protein supplementation following [Ex + whey], completing only the exercise intervention [Ex group] and ingestion of the whey protein supplementation only [Whey group]).

SMI, Skeletal muscle mass index.

ぱく質の併用介入が各単独介入と比べて，介入後のSMI や膝伸展筋力の変化率が有意に高值であったことを報告 している ${ }^{10)}$ 。これまでにサルコペニアの寬解者数の減少 や身体的QOL改善をアウトカムとしたRCTの報告はな い. そこで本研究の目的はサルコペニアに該当する高齢 女性を対象とし、レジスタンス運動と乳清たんぱく質の 摂取の併用介入が各単独介入群と比べ, サルコペニアと その診断構成要素の寛解，さらには身体的QOL改善に 与える効果の可能性について，フェーズ Iの RCTで検 証することである。

本研究の結果, レジスタンス運動と乳清たんぱく質を
併用介入することで高齢女性のSMI低下と握力低下あ りを有意に減少させ，その結果サルコペニアの寛解者数 が有意に減少し，身体的QOLを改善することができた。 一方で，レジスタンス運動群は介入後，骨格筋量や筋力 の值が有意に増加したが，サルコペニアの寛解と身体的 QOLを改善することができなかった。また，乳清群は 介入後，身体的 QOLの改善を認めず，歩行速度が有意 に低下した。従って、レジスタンス運動と乳清たんぱく 質の摂取を併用介入することで高齢女性のSMI 低下と 握力低下， サルコペニアの寛解，身体的QOLが高まり， 複数のアウトカム改善に貢献できることが示された。し 
Table 4. Comparison of physical characteristics and nutritional intake pre- and post-intervention

\begin{tabular}{|c|c|c|c|c|c|c|c|c|c|}
\hline \multirow[b]{3}{*}{ Body weight (kg) } & \multicolumn{3}{|c|}{ Ex group $(n=19)$} & \multicolumn{3}{|c|}{ Whey group $(n=20)$} & \multicolumn{3}{|c|}{ Ex + Whey group $(n=20)$} \\
\hline & \multicolumn{2}{|c|}{ intervention } & $\begin{array}{c}\text { P-value } \\
\text { vs } \\
\text { within }\end{array}$ & Pre- & $\begin{array}{l}\text { Post- } \\
\text { ntion }\end{array}$ & $\begin{array}{c}\text { P-value } \\
\qquad \text { vs } \\
\text { within }\end{array}$ & \multicolumn{2}{|c|}{ intervention } & $\begin{array}{l}P \text {-value } \\
\qquad v s \\
\text { within }\end{array}$ \\
\hline & 43.4(41.5,41.3) & 44.5(41.3,46.5) & 0.020 & 44.5(40.7,47.7) & 45.2(41.7,48.0) & 0.009 & $45.0(42.6,46.9)$ & 45.5(43.0,48.2) & 0.002 \\
\hline SMI $\left(\mathrm{kg} / \mathrm{m}^{2}\right)$ & $5.23(4.81,5.51)$ & $5.31(4.77,5.62)$ & 0.024 & $5.43(4.99,5.59)$ & $5.50(5.04,5.65)$ & 0.003 & $5.39(5.06,5.58)$ & $5.46(5.12,5.71)$ & 0.003 \\
\hline Grip strength (kg) & $16.1(14.5,17.1)$ & $17.0(14.7,17.8)$ & 0.015 & $15.9(15.0,16.8)$ & $15.8(14.8,17.0)$ & 0.305 & $16.5(15.5,17.0)$ & $17.4(15.4,18.0)$ & 0.010 \\
\hline Knee extension strength $(\mathrm{kg})$ & $13.0 \pm 5.2$ & $13.5 \pm 5.2$ & 0.012 & $13.2 \pm 2.5$ & $13.0 \pm 2.7$ & 0.167 & $13.8 \pm 2.5$ & $14.4 \pm 2.6$ & 0.001 \\
\hline Gait speed (m/sec) & $1.04 \pm 0.21$ & $1.04 \pm 0.22$ & 0.722 & $0.98 \pm 0.17$ & $0.96 \pm 0.19$ & 0.048 & $1.03 \pm 0.25$ & $1.02 \pm 0.24$ & 0.607 \\
\hline QOL (score) & $44.0 \pm 2.3$ & $44.4 \pm 2.4$ & 0.324 & $41.7 \pm 3.9$ & $41.7 \pm 3.8$ & 0.996 & $42.6 \pm 3.8$ & $44.3 \pm 3.3$ & 0.027 \\
\hline $\begin{array}{l}\text { Total energy intake/ target } \\
\text { IBW (kcal/target BW kcal) }\end{array}$ & $28.4(27.3,31.0)$ & $31.7(30.6,32.9)$ & $<0.001$ & $29.2(27.7,30.3)$ & $31.3(30.3,32.0)$ & $<0.001$ & $28.8(27.0,31.5)$ & $31.0(30.2,32.5)$ & $<0.001$ \\
\hline $\begin{array}{l}\text { Total protein intake/ target } \\
\mathrm{BW}(\mathrm{g} / \text { target } \mathrm{BW} \mathrm{kg})\end{array}$ & $1.05(0.98,1.15)$ & $1.22(1.19,1.27)$ & $<0.001$ & $1.02(0.91,1.11)$ & $1.24(1.15,1.26)$ & $<0.001$ & $1.07(0.99,1.18)$ & $1.23(1.18,1.25)$ & $<0.001$ \\
\hline $\begin{array}{l}\text { Total protein intake/ actual } \\
\mathrm{BW}(\mathrm{g} / \text { actual } \mathrm{BW} \mathrm{kg})\end{array}$ & $1.18(1.13,1.26)$ & $1.37(1.28,1.43)$ & $<0.001$ & $1.19(0.98,1.29)$ & $1.31(1.21,1.52)$ & $<0.001$ & $1.20(1.07,1.23)$ & $1.30(1.27,1.39)$ & 0.002 \\
\hline
\end{tabular}

Average \pm standard deviation, or median (interquartile range). Between-group differences were Paired t-test and Wilcoxon signed rank test.

24-week intervention period, for the three experimental groups (completing the exercise intervention with whey protein supplementation following [Ex +whey], completing only the exercise intervention [Ex group] and ingestion of the whey protein only [Whey group]). SMI, Skeletal muscle mass index; QOL, Quality of life; BW, the body weight

Table 5. Change in physical characteristics from baseline to the post of the 24-week intervention period

\begin{tabular}{|l|c|cc|ccc|}
\hline & Ex group $(\mathrm{n}=19)$ & Whey group $(\mathrm{n}=20)$ & $\begin{array}{c}P \text {-value } \\
\text { ExvsWhey }\end{array}$ & $\begin{array}{c}\text { Ex+Whey group } \\
(\mathrm{n}=20)\end{array}$ & $\begin{array}{c}P \text {-value } \\
\text { Ex+Whey } \\
\text { vsEx }\end{array}$ & $\begin{array}{c}P \text {-value } \\
\text { Ex+Whey } \\
\text { vsWhey }\end{array}$ \\
\hline$\% \Delta$ body weight $(\mathrm{kg})$ & $1.65(-0.12,3.05)$ & $1.47(0.30,2.27)$ & 0.888 & $1.99(0.88,3.00)$ & 0.704 & 0.344 \\
$\% \Delta$ SMI $\left(\mathrm{kg} / \mathrm{m}^{2}\right)$ & $1.58(-0.61,2.77)$ & $2.18(0.78,2.67)$ & 0.518 & $2.48(0.26,4.11)$ & 0.339 & 0.449 \\
$\% \Delta$ grip strength $(\mathrm{kg})$ & $3.57(1.74,6.42)$ & $-1.37(-3.18,1.42)$ & $\mathbf{0 . 0 0 6}$ & $5.29(1.33,6.87)$ & 0.663 & $\mathbf{0 . 0 0 7}$ \\
$\% \Delta$ knee extension strength $(\mathrm{kg})$ & $3.45(0.75,7.59)$ & $-2.54(-5.77,3.06)$ & $\mathbf{0 . 0 0 5}$ & $4.48(-7.75,6.68)$ & 0.663 & $\mathbf{0 . 0 0 2}$ \\
$\% \Delta$ gait speed $(\mathrm{m} / \mathrm{sec})$ & $0.54(-1.09,2.38)$ & $-1.97(-3.48,0.66)$ & 0.136 & $2.13(-2.88,4.00)$ & 0.715 & $\mathbf{0 . 0 4 5}$ \\
$\% \Delta$ QOL (score) & $1.54(-2.10,3.25)$ & $-1.52(-4.61,4.02)$ & 0.563 & $4.20(-1.25,8.16)$ & 0.181 & 0.123 \\
\hline
\end{tabular}

Median (interquartile range). Between-group differences were evaluated using a Mann-Whitney U test; the P-value is shown. 24-week intervention period, for the three experimental groups (completing the exercise intervention with whey protein supplementation following [Ex + whey], completing only the exercise intervention [Ex group] and ingestion of the whey protein supplementation only [Whey group]).

Change $(\% \Delta)$ in bodyweight, skeletal muscle mass index (SMI), grip strength, knee extension strength, gait speed, and physical QOL (quality of life) from baseline to the end of the 24-week intervention period, for the three experimental groups (completing the exercise intervention with whey protein supplementation following [Ex + Whey], completing only the exercise intervention [Ex group] and ingestion of the whey protein supplementation only [Whey group]).

かし，従来の標準的な治療法である運動群と比べ, 介入 後の運動+乳清群はサルコペニアの寛解者数が有意に少 ない傾向（ $\mathrm{p}=0.070 ）$ にあるものの, 統計学的な有意差

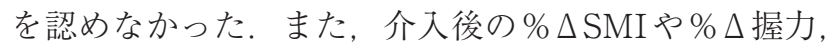
$\% \Delta$ 膝伸展筋力の増加に群間差を認めなかった，従って， 本研究では併用介入の明らかな有効性を示すことはでき なかった。

これまでにサルコペニアを発症した高齢者を対象とし た骨格筋量, 筋力, 身体機能に対する運動療法と乳清たん ぱく質摂取との併用介入の効果に関するエビデンスは限 られている. 最近のシステマティックレビューおよびメ タアナリシスでは, サルコペニアの寛解と QOLを改善さ
せるための運動療法と栄養療法との併用介入に関する長 期的アウトカムの改善効果は明らかとなっていない5,15). 本研究では, AWGS2014年基準 ${ }^{1)}$ にって定義され, サ ルコペニアと診断された高齢女性を抽出した，我々の知 る限りでは, 本邦におけるサルコペニア寛解者の減少と 身体的 QOLの改善をアウトカムとし, 運動療法と乳清 たんぱく質の併用が各単独介入と比較検証したRCTは ない.2019年に公開されたAWGSのコンセンサスでは, 介入に対する望ましい治療結果及び指標のゴールはサル コペニアを寛解できるか，またはサルコペニア診断の 個々の構成要素（SMI, 握力, 歩行速度）をカットオフ值 以上に寛解できるかであることが示されている ${ }^{16)}$ 。従っ 
て, サルコペニアと各構成要素の寛解者数をアウトカム とした本研究は, 我が国のサルコペニア治療に扔けるエ ビデンス創出に関わる RCT 結果のひとつとして重要な 意味を持つ.

PROT-AGE study ${ }^{3)}$ および, The European Society for Clinical Nutrition and Metabolism ${ }^{4)}$ の見解によれば, 高齢者の筋たんぱく合成量を高めるためには牛乳由来の 乳清たんぱく質摂取が推奨されている。筋たんぱく合成 はレジスタンス運動終了 $1-3$ 時間後に最も高まるた め, 消化吸収の早い牛乳由来の乳清たんぱく質の早急な 摂取が骨格筋への筋たんぱく蓄積に効率よく寄与できる と考えられている6,8,17).さらに乳清たんぱく質には, 筋 たんぱく合成を高める分岐鎖アミノ酸の 1 つであるロイ シンが多く含まれており, 高齢者の骨格筋量の増加には ロイシン摂取量は 1 食あたり $2,500 \mathrm{mg}$ 程度必要である ${ }^{3)}$. ロイシンは哺乳類ラパマイシン標的蛋白質シグナル経路 を活性化させ, mRNAの翻訳調節を介してたんぱく質同 化作用に関連している ${ }^{6,18)}$. 筆者らの先行研究結果では, サルコペニアやフレイルティを併発した高齢者の食習慣 の特徵として, 総エネルギーや総たんぱく質摂取量が不 足していることを明らかにしており ${ }^{19)}$ ，骨格筋量を維 持するためには食事からたんぱく質やロイシンを適切に 摂取する必要がある. Yoshimura ${ }^{20)}$ の報告によれば, 脳卒中の既往を認めるサルコペニア患者を対象に 8 週間 に渡りレジスタンス運動とロイシン $1,200 \mathrm{mg}$ が含まれた 必須アミノ酸（たんぱく質 $3.0 \mathrm{~g}$ ）サプリメントの摂取を 併用介入したところ，レジスタンス運動単独介入と比べ SMIや握力が有意に増加したことを報告している，従っ て，サルコペニア治療を目的としたレジスタンス運動の 介入を行う際，ロイシンや必須アミノ酸が多く含まれる 乳清たんぱく質と併用介入した方がサルコペニア宽解へ 与える効果は高いと考えられている.

一般高齢者において骨格筋量や筋力を増加させ，身体 機能を向上させるためには，レジスタンス運動を中心と した運動療法が標準的な介入方法と考えられている。本 研究では, 介入前と比べ介入後, 運動群の握力は $3.57 \%$ 増加し, 滕伸展筋力は $3.45 \%$ 増加していた。本研究は前 腕部を意識したレジスタンス運動を採用してはいない が，上腕部のアームカールやプッシュアップを反復する 際にエラスティックバンドを握り締めるため, 運動介入 した群は握力が増加した可能性がある。AWGS2014年 の基準でサルコペニアに該当する香港地域在住高齢者を 対象としたZHUらの RCT の報告によれば21)，40\%RM の負荷で自体重やエラスティックバンドを利用したレジ スタンス運動を 24 週間に渡り実践したところ, 握力が $3.53 \%$, 膝伸展筋力が $2.32 \%$ 有意に増加しており, 本研 究と同等の増加率を示している. ZHU ら ${ }^{21)}$ や本研究で 採用したレジスタンス運動方法でも握力や膝伸展筋力
が増加し, サルコペ二ア治療に期待できる可能性があ る. 本研究のサルコペニア高齢者のレジスタンス運動の 実践率は運動群 $73.4 \pm 4.1 \%$ ，運動十乳清群は $74.6 \pm 6.4 \%$ であった，Kim らの虚弱高齢女性を対象としたRCT ${ }^{22)}$ ではアンクルウエイトや自体重, エラスティックバンド を利用した運動とアミノ酸摂取を介入した群の運動実 践率は $70.3 \%$ であり, 本研究の運動実践率と同等であっ た．健常高齢女性を対象とした筆者らのフェーズ I の $\mathrm{RCT}^{10)}$ では 24 週間の介入中の運動実践率は, 運動群で $90.1 \%$, 運動+乳清群で $86.6 \%$ であった，本研究では，筆 者らのフェーズ I ${ }^{10)}$ と同様に安全かつ簡便に実践でき る自体重やラバーバンドを活用した運動方法を採用した が，本研究の対象者は高齢かつサルコペニアを伴うため 実践頻度が少なかった可能性がある。また，フェーズ I の $\mathrm{RCT}^{10)}$ では 24 週間後の運動群の $\% \Delta \mathrm{SMI}$ は中央值で $2.0 \%$, \% $\Delta$ 膝伸展筋力は $5.5 \%$, 運動+乳清群の $\% \Delta \mathrm{SMI}$ は $3.7 \%, \% \Delta$ 膝伸展筋力は $7.2 \%$ に対して, 本研究のフェー ズ II の RCT では運動群の \% $\Delta \mathrm{SMI} 1.58 \% ％ ％$ 膝伸展 筋力は $3.45 \%$, 運動十乳清群の $\% \Delta \mathrm{SMI}$ は $2.48 \%, \% \Delta$ 膝 伸展筋力は $4.48 \%$ であった。 フェーズ I ${ }^{10)}$ と比べ本研究 では骨格筋量や筋力の増加率は少なかった要因のひとつ として，運動実践率が少なかったことが挙げられる。

本研究では乳清たんぱく質の単独介入は筋肉量を増や しサルコペニアを寛解できたが，握力の低下を寛解でき ず，さらには滕伸展筋力の増加を認めなかった。健常高 齢女性を対象とした筆者らのフェーズ I の RCT 検証で は10), 乳清たんぱく質の単独摂取では握力や膝伸展筋力 の増加を認めなかった。従って, サルコペニアおよび健 常高齢女性共に乳清たんぱくの単独介入だけでは, 筋力 の改善を見込めない可能性が示唆される。これまでの先 行研究では, 骨格筋肉量の低下と比べ, 筋力低下の方が 高齢者の日常生活機能や転倒再発，死亡リスクに大きく 影響する因子であることが報告されており ${ }^{23)}$ ，サルコペ ニア治療の主要アウトカムとして, 介入後の筋力増加が 重要な意味を持つ。骨格筋力の質的向上には運動療法の 介入が必須であろう。また，レジスタンス運動と乳清 たんぱくの併用介入した群は介入後の身体的 QOLが有 意に改善したが，一方で各単独介入群に打いて身体的 QOLの改善を認めなかった。これまでの先行研究によ ればサルコペニアの高齢者は健常高齢者と比べ，歩行機 能や身体機能等の低下に伴う身体的 QOLが低下してい ることが報告されており, サルコペニア寛解の臨床型ア ウトカムと $\mathrm{QOL}$ 等の患者立脚型のアウトカムの収集が 要求される ${ }^{16,24)}$ 。これまでにサルコペニア治療を目的と した先行研究ではQOLの改善をアウトカムとした無作 為化比較試験は少ない. 2019年の AWGS コンセンサス ではQOLの測定や主観的な健康指標といった，患者立 脚型アウトカムの評価が重要であると示されている ${ }^{16)}$. 
我が国の身体的 QOL の標準化得点である50.0点と比べ ると ${ }^{12)}$, 本研究では対象者の介入前のQOL スコアが下 回って扮り, 運動と栄養療法の併用介入を行うことで改 善する余地があると考えられる。本研究では, 運動と乳 清たんぱく質の併用介入が臨床的アウトカムと患者立脚 型アウトカムの両アウトカムへ与える効果検証すること ができたため, 本結果は我が国のサルコペニア治療に重 要な意味を持つ.

本研究では, 運動+乳清群は運動群と比べ, 介入後の サルコペニア寬解者数に有意な違いはなく, 介入後の SMI, 握力, 膝伸展筋力, 歩行速度の変化率も有意な群 間差を認めなかった。介入後, 運動+乳清群でサルコペ ニアを寛解した 7 名の高齢女性の臨床的特徵を比較した ところ, 介入中の運動実践と乳清たんぱく質摂取の遵 守率と介入終了時の総たんぱく質摂取量が高值であっ た。本研究では全症例共に介入期間中に総たんぱく質摂 取量を $1.2 \mathrm{~g} / \mathrm{kg}$ 目標体重/日以上摂取できるような食事 管理を乳清たんぱく質のサプリメンテーション介入と同 時並行して行ったため, 乳清たんぱく質サプリメントの 明らかな効果が得られなかった可能性がある，筆者らの フェーズ I の $\mathrm{RCT}^{10)}$ では, 運動+乳清群は各単独群と 比べて\% $\Delta \mathrm{SMI} \% \Delta$ 筋力の変化率が有意に高く有意な 群間差を認めている. 本研究 (フェーズII) とは異なり, フェーズ Iでは介入前と介入中共に総たんぱく質量を適 切に充足できた条件下でRCT検証を行っており，運動 後の乳清たんぱく質のサプリメンテーション効果をアウ トカムに直接反映することができたと予想される，従っ て, サルコペニアの治療介入に打いて, 運動実践頻度や 乳清たんぱく質のサプリメンテーション摂取頻度を高め るだけではなく，毎食の食事に含まれるたんぱく質量を 不足することなく適切に摂取することもサルコペニア治 療に重要である。

運動群, 乳清群, 運動+乳清群は介入前と比べ介入 後の総エネルギーや総たんぱく質摂取量の増加を認め, SMIや体重が有意に増加していた。本研究より体重や SMI值の増加に扔いて, 日常生活で総エネルギーや総た んぱく質摂取量を増加させた食事管理の果たす役割が大 きいことが示唆される。一方, ZHUらの報告によれば21), 介入期間の総エネルギーや総たんぱく質摂取量を充足さ せた食事管理は不明であり，レジスタンス運動の単独介 入ではSMI増加を認めていない。従って, 乳清たんぱ く質のサプリメントを併用しなくても, 本研究のように 不足した総エネルギーや総たんぱく質量を充足した条件 下でレジスタンス運動を行えば，サルコペニア寛解に至 らないが, SMI值や体重值の増加が期待できる可能性が ある、

フェーズ I の $\mathrm{RCT}^{10)}$ では 1 回あたりの試験食のたん

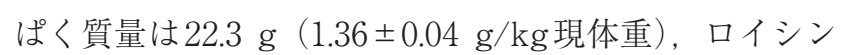

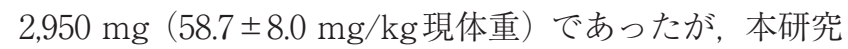
では 1 回あたりのたんぱく質量は $11.0 \mathrm{~g} （ 1.21 \pm 0.06 \mathrm{~g} /$ $\mathrm{kg}$ 現体重), $2,300 \mathrm{mg}(54.4 \pm 6.8 \mathrm{mg} / \mathrm{kg}$ 現体重)であっ た。フェーズ $\mathrm{I}^{10)}$ と本研究のフェーズIに打いて, 試験 食 1 食で摂取できる現体重当たりのロイシン量に差はみ られないが，フェーズIIはたんぱく質量を低用量に設定 したため, 運動+乳清群は運動群と比べ明らかな併用効 果が得られなかったことも要因のひとつとして挙げられ る。一方, フェーズIでは試験食摂取に伴い乳清群と運 動+乳清群共に総エネルギー摂取量や総たんぱく質摂取 量が減ることはなかったため, サプリメンメーションに よる食事量の減少の影響は少ないと考えられる。また, 乳清たんぱく質のサプリメンテーションに伴う明らかな 有害事象は発生しなかったため, 今後はたんぱく質量を 高用量に設定した条件下での介入研究も検証すべきであ ろう。

本研究の限界点を以下に示す. 本研究はサンプル数 が少ない探索的試験であった，今後サンプル数を増や し，運動及び乳清たんぱく質摂取の有効性について明ら かにしていく必要がある。本研究では，評価項目に血清 IGF-1などの筋たんぱく合成のバイオマーカ等を収集で きなかった。本研究では乳清群, 運動群, 運動十乳清群 ともに歩行速度の改善を認めなかったため, レジスタン 久運動以外の複合的な運動介入方法も検討する必要があ る。本研究では, レジスタンス運動を対象者の主観的運 動強度で負荷設定を行っており, 被験者間での強度設定 の誤差の可能性を排除できず大きな限界点として挙げら れる. 本研究では多周波数のインピーダンス法を用いて SMIを算出しており，二重エネルギーX線吸収測定法と くらべ精度が劣る可能性がある ${ }^{25)}$. AWGS2019年のコ ンセンサスでは多周波数のインピーダンス法でのSMI 測定を推奨しているが16), 測定結果の解釈に注意が必要 である．また，本研究では研究デザインの設定に複数の 課題が挙げられる。本研究は対象者には男性が含まれて おらず性差による違いを検証できていない，対象者の生 活環境の属性が異なる集団を対象としており，介入の実 践方法や実践率に影響があった可能性もある。ささらに研 究デザインとして, 介入中の参集及び訪問型指導の導入 率に有意な違いはないが，非盲検法であるため介入期間 中の対象者や研究者及び研究協力者の行動や介入等にバ イアスが生じている可能性が危惧される。本研究は運動 と乳清たんぱく質の併用療法の有用性を明らかにするた め, 研究デザインとして運動または乳清たんぱく質の単 独群と併用群の 3 群を設定したが, 介入を行わない対照 群を設定しなかった。 今後, 各単独介入の有用性につい て明らかにするためにも対照群を設定した研究デザイン でRCT検証する必要もあるだろう。そして, 介入前の身 体活動量を収集できたが，介入中の身体活動量を収集で 
きなかった，石原式身長測定法で身長を計測したサルコ ペニア症例は13名であった。最後に本研究では目標体重 あたりの総エネルギーと総たんぱく質量を設定し食事管 理を行うことにしたが，近年では高齢者の目標BMIは， BMI21.5-24.9の範囲から個別に算出する方法が推奨さ れている ${ }^{26)}$. 一律に目標BMIを 22.0 に設定することなく, 最適なBMIを個別に設定し,食事管理を行う必要がある.

\section{結 論}

本研究の結果, レジスタンス運動と乳清たんぱく質の 各単独での介入と比べ, 運動+乳清群はサルコペニアあ りとSMI低下あり, 握力低下ありのいずれも寛解するこ とができ，さらには運動＋乳清群のみ身体的 QOL が高 まり，複数のアウトカム改善に貢献できることが明らか となった。しかし, 運動+乳清群は運動群また乳清群と 比べて, 各アウトカムの寛解者数と変化率に有意な群間 差を認めず, 本研究では運動と乳清たんぱく質摂取の併 用介入が単独介入と比べ，明らかな有効性を示すことが できなかった。

\section{謝 辞}

本研究にご参加・ご協力・ご助言頂いた JA グループ兵庫 関連事業所の皆さま, 参加施設の皆さま, NPO 法人姫路こ ころの事業団の皆さまには心より感謝申し上げます。

\section{資 金}

本研究は一般財団法人糧食研究会の研究助成金（一般公 募研究）を使用して行った.

\section{利益相反}

著者, 森博康は一般財団法人糧食研究会の研究助成金 (一 般公募研究) の提供を受けた。共著者, 徳田泰伸は申告すべ き利益相反はない.

\section{著者貢献}

著者 HM と共著者 YTは研究デザインとプロトコルを概 念化し, 研究計画を決定した。著者 HMはデータ収集と組 み立て，データの分析と解釈を担当した。草稿は著者 $\mathrm{HM}$ が担当した。著者 HM と共著者 YTは, 原稿を批判的にレ ビューし，修正し，投稿を承認した。

\section{引用文献}

1) Chen LK, Liu LK, Woo J, Assantachai P, Auyeung TW, Bahyah KS, Chou MY, Chen LY, Hsu PS, Krairit O, Lee JS, Lee WJ, Lee Y, Liang CK, Limpawattana P, Lin CS, Peng LN, Satake S, Suzuki T, Won CW, Wu CH, Wu SN, Zhang T, Zeng P, Akishita M, Arai H. Sarcopenia in Asia: consensus report of the Asian Working Group for Sarcopenia. J Am Med Dir Assoc 15: 95-101, 2014. doi: 10.1016/j.jamda.2013.11.025.

2）桝本妙子, 山田陽介, 山田 実, 中谷友樹, 三宅基子, 渡邊
裕也, 吉田 司, 横山慶一, 山縣恵美, 伊達平和, 南里妃名 子, 小松光代, 吉中康子, 藤原佳典, 岡山寧子, 木村みさ か：地域在住自立高齢者における転倒リスクの関連要 因とその性差 亀岡スタディ, 日本公衆衛生学雑誌, 62: 390-401, 2015. doi: 10.11236/jph.62.8_390.

3) Bauer J, Biolo G, Cederholm T, Cesari M, Cruz-Jentoft AJ, Morley JE, Phillips S, Sieber C, Stehle P, Teta D, Visvanathan R, Volpi E, Boirie Y. Evidence-based recommendations for optimal dietary protein intake in older people: a position paper from the PROT-AGE Study Group. J Am Med Dir Assoc 14: 542-559, 2013. doi: 10.1016/j.jamda.2013.05.021.

4) Volkert D, Beck AM, Cederholm T, Cruz-Jentoft A, Goisser S, Hooper L, Kiesswetter E, Maggio M, Raynaud-Simon A, Sieber CC, Sobotka L, van Asselt D, Wirth R, Bischoff SC. ESPEN guideline on clinical nutrition and hydration in geriatrics. Clin Nutr 38: 1047, 2019. doi: 10.1016/j.clnu.2018.05.024.

5）日本サルコペニア・フレイル学会編, サルコペニア診 療ガイドライン 2017 年版, ライフサイエンス出版, 東京, 54-66, 2017.

6) Jordan LY, Melanson EL, Melby CL, Hickey MS, Miller BF. Nitrogen balance in older individuals in energy balance depends on timing of protein intake. $J$ Gerontol A Biol Sci Med Sci 65: 1068-1076, 2010. doi: 10.1093/gerona/glq123.

7) Kramer IF, Verdijk LB, Hamer HM, Verlaan S, Luiking Y, Kouw IW, Senden JM, van Kranenburg J, Gijsen AP, Poeze M, van Loon LJ. Impact of the macronutrient composition of a nutritional supplement on muscle protein synthesis rates in older men: a randomized, double blind, controlled trial. J Clin Endocrinol Metab 100: 4124-4132, 2015. doi: 10.1210/jc.2015-2352.

8) Shad BJ, Thompson JL, Breen L. Does the muscle protein synthetic response to exercise and amino acidbased nutrition diminish with advancing age? A systematic review. Am J Physiol Endocrinol Metab 311: 803-817, 2016. doi: 10.1152/ajpendo.00213.2016.

9) Paddon-Jones D, Short KR, Campbell WW, Volpi E, Wolfe RR. Role of dietary protein in the sarcopenia of aging. Am J Clin Nutr 87: 1562-1566, 2008. doi: 10.1093/ajcn/87.5.1562S.

10) Mori H, Tokuda Y. Effect of whey protein supplementation after resistance exercise on the muscle mass and physical function of healthy older women: A randomized controlled trial. Geriatr Gerontol Int 18: 13981404, 2018. doi: 10.1111/ggi.13499.

11）望月弘彦：総論 身体計測の方法, 日本静脈経腸栄養学会 雑誌, 32: 1137-1141, 2017. doi: 10.11244/jspen.32.1137.

12）福原俊一, 鈴鴨よしみ. SF-36v2[TM] 日本語版マニュ アル：健康関連 QOL 尺度, 健康医療評価研究機構, 東京, 123, 2011.

13）厚生労働省. 日本人の食事摂取基準（2015年版）厚生労 働省「日本人の食事摂取基準」策定検討会報告書, 第一 出版, 東京, 2015.

14) Rubenstein LZ, Harker JO, Salvà A, Guigoz Y, Vellas B. Screening for undernutrition in geriatric practice: de- 
veloping the Short-Form Mini Nutritional Assessment (MNA-SF). J Geront A Biol Sci Med Sci 56: 366-372, 2001. doi: 10.1093/gerona/56.6.m366.

15) Yoshimura Y, Wakabayashi H, Yamada M, Kim H, Harada A, Arai H. Interventions for Treating Sarcopenia: A Systematic Review and Meta-Analysis of Randomized Controlled Studies. J Am Med Dir Assoc 18: 553. e1-553.e16, 2017. doi: 10.1016/j.jamda.2017.03.019.

16) Chen LK, Woo J, Assantachai P, Auyeung TW, Chou MY, Iijima K, Jang HC, Kang L, Kim M, Kim S, Kojima T, Kuzuya M, Lee JSW, Lee SY, Lee WJ, Lee Y, Liang CK, Lim JY, Lim WS, Peng LN, Sugimoto K, Tanaka T, Won CW, Yamada M, Zhang T, Akishita M, Arai H. Asian Working Group for Sarcopenia: 2019 Consensus Update on Sarcopenia Diagnosis and Treatment. J Am Med Dir Assoc 21: 752-758, 2020. doi: 10.1016/ j.jamda.2020.03.018.

17) Børsheim E, Bui QT, Tissier S, Kobayashi H, Ferrando AA, Wolfe RR. Effect of amino acid supplementation on muscle mass, strength and physical function in elderly. Clin Nutr 27: 189-195, 2008. doi: 10.1016/ j.clnu.2008.01.001.

18) Katsanos CS, Kobayashi H, Sheffield-Moore M, Aarsland A, Wolfe RR. A high proportion of leucine is required for optimal stimulation of the rate of muscle protein synthesis by essential amino acids in the elderly. Am J Physiol Endocrinol Metab 291: 381-387, 2006. doi: 10.1152/ajpendo.00488.2005.

19) Mori H, Tokuda Y. Differences and overlap between sarcopenia and physical frailty in older communitydwelling Japanese. Asia Pac J Clin Nutr 28: 157-165, 2019. doi: 10.6133/apjcn.201903_28(1).0021.

20) Yoshimura $Y$, Bise T, Shimazu S, Tanoue M, Tomioka Y, Araki M, Nishino T, Kuzuhara A, Takatsuki F. Effects of a leucine-enriched amino acid supplement on muscle mass, muscle strength, and physical function in post-stroke patients with sarcopenia: A randomized controlled trial. Nutrition 58: 1-6, 2019. doi: 10.1016/ j.nut.2018.05.028

21) Zhu LY, Chan R, Kwok T, Cheng KCC, Ha A, Woo J. Effects of exercise and nutrition supplementation in community-dwelling older Chinese people with sarcopenia: a randomized controlled trial. Age Ageing 48: 220-228, 2019. doi: 10.1093/ageing/afy179.

22) Kim HK, Suzuki T, Saito K, Yoshida H, Kobayashi H, Kato H, Katayama M. Effects of exercise and amino acid supplementation on body composition and physical function in community-dwelling elderly Japanese sarcopenic women: a randomized controlled trial. $J$ Am Geriatr Soc 60: 16-23, 2012. doi: 10.1111/j.15325415.2011.03776.x.

23) Newman AB, Kupelian V, Visser M, Simonsick EM, Goodpaster BH, Kritchevsky SB, Tylavsky FA, Rubin SM, Harris TB. Strength, but not muscle mass, is associated with mortality in the health, aging and body composition study cohort. J Gerontol A Biol Sci Med Sci 61: 72-77, 2006. doi: 10.1093/gerona/61.1.72.

24) Rizzoli R, Reginster JY, Arnal JF, Bautmans I, Beaudart C, Bischoff-Ferrari H, Biver E, Boonen S, Brandi ML, Chines A, Cooper C, Epstein S, Fielding RA, Goodpaster B, Kanis JA, Kaufman JM, Laslop A, Malafarina V, Mañas LR, Mitlak BH, Oreffo RO, Petermans J, Reid K, Rolland Y, Sayer AA, Tsouderos Y, Visser M, Bruyère O. Quality of life in sarcopenia and frailty. Calcif Tissue Int 93: 101-120, 2013. doi: 10.1007/s00223013-9758-y.

25) Ling $\mathrm{CH}$, de Craen AJ, Slagboom PE, Gunn DA, Stokkel MP, Westendorp RG, Maier AB. Accuracy of direct segmental multi-frequency bioimpedance analysis in the assessment of total body and segmental body composition in middle-aged adult population. Clin Nutr 30: 610-615, 2011. doi: 10.1016/j.clnu.2011.04.001.

26）厚生労働省. 日本人の食事摂取基準（2020年版）厚生労 働省「日本人の食事摂取基準」策定検討会報告書, 第一 出版, 東京, 2020. 